Journal of Food Technology and Agroindustry Volume 3 No 1 Februari 2021

P-ISSN: 2656-0623

E-ISSN: 2684-8252

\title{
STRATEGI BRANDING UNTUK MEMBANGUN IMAGE POSITIF PANGAN LOKAL BAGI USAHA MIKRO KECIL DAN MENENGAH
}

\author{
Dyah Panuntun Utami \\ Program Studi Agribisnis Universitas Muhammadiyah Purworejo \\ email:dyahpanuntunutami@gmail.com
}

\begin{abstract}
ABSTRAK
Indonesia memiliki jenis pangan lokal yang sangat banyak dengan keunikan masingmasing. Potensi tersebut belum diimbangi dengan meningkatnya minat masyarakat dalam mengkonsumsi pangan lokal. Hal ini disebabkan UMKM masih rendah dalam menggunakan inovasi teknologi pengolahan pangan dan membangun image produk pangan lokal. Untuk membangun image positif pangan lokal memerlukan suatu kajian agar diperoleh konsep branding yang tepat. Metode kajian menggunakan paradigma postpositivistik dan pola berpikir induktif. Hasil kajian ini menunjukkan strategi branding difokuskan pada product branding. Membangun image positif pangan lokal dilakukan dengan memperbaiki tampilan fisik produk dengan melakukan inovasi pengolahan, memperbaiki kemasan, memberikan labelling, dan memperhatikan selera konsumen, kemudian mengkomunikasikan secara intensif kepada masyarakat. Konsep branding dibuat sederhana, mengena di hati masyarakat, dan harus konsisten dalam menjaga nilai produk. UMKM harus tekun dan kreatif menemukan ide untuk menjaga loyalitas konsumen.
\end{abstract}

Kata kunci: branding; image produk; pangan lokal

\begin{abstract}
Indonesia has many types of local food with their own uniqueness. This potential has not been matched by people's interest in consuming local food. This is because micro small and medium enterprises are still low in using food processing technology innovations and building the image of local food products. Building a positive image of local food requires a study to obtain the right branding concept. The study method uses a post positivistic paradigm and inductive thinking patterns. This study shows that the branding strategy is focused on product branding. Building a positive image of local food is done by improving the physical appearance of the product by processing innovation, improving packaging, labeling, and paying attention to consumer tastes, then communicating intensively to the public. The branding concept is made simple, hits the hearts of the public, and must be consistent in maintaining the value of the product. Micro, small and medium enterprises must be diligent and creative in finding ideas to maintain consumer loyalty.
\end{abstract}

Keywords: branding, local food, product image 


\section{PENDAHULUAN}

Indonesia memiliki kekayaan alam berupa pangan lokal yamg sangat berlimpah. Pangan lokal memiliki potensi sebagai salah satu sumber pangan dalam diversifikasi atau penganekaragaman pangan. Kebijakan pemerintah dalam pengembangan pangan lokal dituangkan dalam UU No. 18 Tahun 2012 pasal 41 dan 42. Kebijakan penganekaragaman pangan sebagaimana dimaksud dalam Pasal 41 antara lain adalah pengoptimalan pangan lokal, pengembangan teknologi usaha pengembangan pangan lokal, dan pengembangan industri berbasis pangan lokal.

Usaha Mikro Kecil dan Menengah (UMKM) di Indonesia yang memproduksi pangan lokal cukup banyak. Namun karena belum semua UMKM menggunakan teknologi pengolahan modern sehingga pamor pangan lokal belum secemerlang makanan instan yang lain. Indonesia memiliki jenis pangan lokal sangat banyak. Pangan lokal menjadi makanan khas tradisional suatu daerah dengan keunikan masing-masing. Hal ini sesuai dengan definisi dari Hariyadi (2010) dalam Yuliatmoko (2011) yang menyatakan bahwa pangan lokal merupakan pangan yang diproduksi, berkembang dan dikonsumsi di suatu daerah, menggunakan bahan baku, teknologi dan pengetahuan lokal. Oleh karena itu pangan lokal biasanya berkaitan erat dengan budaya suatu daerah.

Potensi berlimpah tersebut saat ini belum diimbangi dengan meningkatnya minat masyarakat dalam mengkonsumsi pangan lokal. Hal ini disebabkan industri yang mengolah pangan lokal belum semuanya mampu menggunakan teknologi pengolahan pangan untuk menghasilkan pangan lokal yang prestise dan bergengsi. Olahan pangan lokal yang memiliki daya saing tinggi saat ini relative sedikit. Sementara selera dan preferensi konsumen terhadap pangan telah mengalami pergeseran.

Preferensi masyarakat dalam mengkonsumsi pangan telah bergeser kearah manfaat pangan bagi tubuh, keamanan pangan, dan juga memiliki nilai prestise. Konsumsi pangan tidak sekedar memenuhi motif dan kebutuhan dasar manusia yaitu rasa lapar serta tercukupinya kebutuhan gizi tetapi juga sebagai aktualisasi diri yang bisa meningkatkan prestise dari diri seseorang. Oleh karena itu sebagian besar masyarakat lebih tertarik memilih produk makanan dengan atribut produk yang lengkap dengan kemasan dan labeling menarik. Informasi kehalalan produk, kode produksi dan masa kadaluwarsa harus tercantum dalam label karena menjadi pertimbangan konsumen memilih suatu produk pangan.

Untuk menarik minat masyarakat terhadap pangan lokal maka diperlukan inovasi dalam pengolahan dan pengemasan. Pangan lokal yang dijual sebagai bahan mentah maka nilai jualnya rendah namun dengan teknologi pengolahan pangan akan dihasilkan berbagai macam produk olahan dengan nilai jual tinggi. Gaya hidup konsumen yang lebih memilih makanan instan tentu saja lebih memilih pangan lokal siap saji dan unik. Teknologi pengolahan akan menghasilkan berbagai macam produk olahan yang unik, menarik serta memiliki nilai tambah tinggi sesuai dengan pendapat Novalinda dan Asni (2013) bahwa teknologi pangan dalam penganekaragaman pangan berperan meningkatkan nilai tambah produk sehingga menarik minat konsumen.

Produk unik dengan kemasan menarik tidak cukup untuk menarik minat konsumen, sehingga diperlukan branding untuk membangun image positif. Nastain (2017) menuliskan bahwa brand tidak hanya sekedar nama dan logo, tetapi brand juga merupakan janji suatu perusahaan kepada pelanggan untuk memberikan apa yang menjadi prinsip brand 
tersebut. Brand tidak hanya sebagai identitas tetapi juga ada nilai-nilai yang ingin disampaikan kepada konsumen. Janji perusahaan untuk memberikan manfaat fungsional, emosional, ekspresi diri dan sosial sehingga brand dinilai unik dan berbeda dari produk lain oleh konsumen. Tahap selanjutnya adalah terwujudlah loyalitas pelanggan.

Kenyataan yang ada saat ini terutama UMKM yang memproduksi pangan lokal masih lemah dalam membangun image produk. Hal ini menjadi salah satu penyebab image pangan lokal rendah dan belum mampu bersaing dengan produk perusahaan besar. Dampak selanjutnya adalah pamor pangan lokal menurun dan mulai ditinggalkan masyarakat. Membangun brand image pangan lokal untuk UMKM memerlukan suatu kajian sehingga diperoleh konsep branding yang tepat untuk mengangkat pamor pangan lokal.

Konsep branding untuk pangan lokal dalam kajian ini difokuskan pada sisi produk. Produk pangan lokal UMKM sebenarnya memiliki kualitas rasa dan mutu yang bagus. Kelemahan pangan lokal adalah inovasi produk, kemasan dan labelling sehingga dinilai kurang prestise oleh masyarakat. Atribut produk menjadi perhatian dalam branding karena yang pertama dilihat konsumen adalah bentuk visual produk. Salah satu atribut produk yang cukup menonjol adalah kemasan.

Produk yang secara visual dapat dilihat dan dirasakan konsumen adalah bentuk, kemasan, manfaat, dan rasa. Keindahan dan keunikan produk dapat divisualisasi melalui kemasan. Oleh karena itu kemasan yang unik, menarik, merk dan logo yang mudah diingat dapat digunakan sebagai strategi branding pangan lokal.

Hal ini sesuai dengan Wirya (1999) dalam Vellina dan Nugroho (2020) yang menyatakan bahwa kemasan produk menarik konsumen jika dibuat dengan penampilan yang atraktif. Untuk membuat kemasan yang atraktif harus didukung dengan daya tarik visual dan daya tarik praktis. Kemasan dengan daya tarik visual menggunakan unsur grafis agar menimbulkan kesan dan persepsi makna tertentu. Berdasarkan kesan dan persepsi tersebut akan mempengaruhi konsumen memberikan respon. Respon dapat bersifat positif maupun negatif. Daya tarik praktis adalah desain kemasan yang secara efektif memberikan dampak efisiensi untuk distributor dan memberikan kemudahan konsumen.

Menurut Siregar, R.A.D, (2017) dalam Wardanu et al. (2018) salah satu cara yang dapat dilakukan UMKM dalam meningkatkan kualitas produknya dengan memaksimalkan fungsi kemasan. Hal tersebut juga sesuai dengan pendapat Cenadi (2000) dalam Wardanu et al. (2018) yang menyatakan bahwa kemasan bukan lagi sebagai pelindung produk yang dikemas saja tetapi juga berfungsi sebagai media komunikasi.

UMKM dengan segala keterbatasan yang dimiliki terutama permodalan dan penguasaan teknologi memerlukan konsep branding yang tepat dan sederhana dalam menjalankan bisnis pangan lokal. Oleh karena itu dalam kajian ini akan membahas tentang pentingnya branding untuk membangun brand image positif dan konsep branding yang tepat untuk mengangkat pamor pangan lokal.

\section{METODE}

Kajian ini merupakan penelitian kepustakaan (library research), yaitu serangkaian kegiatan yang berkenaan dengan pengumpulan data pustaka, membaca, mencatat serta mengolah bahan penelitian. Analisis data berdasarkan bahan-bahan koleksi pustaka tanpa melakukan riset lapangan. Jenis data yang digunakan bersumber dari pustaka hasil penelitian, artikel ilmiah, buku, dan sumber informasi lain yang relevan. Data yang diperoleh selanjutnya dikompilasi, dianalisis, dan disimpulkan sehingga diperoleh suatu kesimpulan (Dapur Ilmiah, 2014) dan Amin (2012). 
Sumber literatur yang digunakan dalam kajian ini berasal dari sumber primer dan sumber sekunder. Sumber primer bersumber dari penulis yang melihat, mengalami, atau mengerjakan sendiri, berupa laporan hasil penelitian, pengabdian masyarakat dan artikel ilmiah yang dipublikasi di jurnal dan bulletin penelitian. Sedangkan sumber sekunder adalah tulisan tentang penelitian orang lain yang tidak disaksikan dan dialami sendiri oleh penulis. Sumber sekunder yang digunakan dalam kajian ini adalah buku dan informasi yang berasal dari blog yang sesuai dengan kajian ini yaitu branding dan strategi branding pangan lokal.

Artikel ini mengkaji pentingnya branding untuk membangun image postitif pangan lokal. Sumber pustaka yang digunakan adalah penelitian terkait pangan lokal, branding, image produk, kemasan, dan konsep strategi branding. Data yang bersumber dari berbagai pustaka selanjutnya dianalisis untuk menjawab tujuan kajian ilmiah ini yaitu branding yang tepat unutk membangun citra positif pangan lokal.

\section{HASIL DAN PEMBAHASAN}

\section{Kajian Teori Brand, Branding dan Image \\ Brand dan branding seringkali diartikan}

sama. Padahal kedua nya memiliki perbedaan yang mendasar. Brand adalah nama, istilah, simbol, desain, atau gabungan dari keempat hal tersebut. Brand sebagai identitas produk perusahaan yang membedakan dengan merek perusahaan lain. Sedangkan branding adalah kegiatan mengkomunikasikan merek atau brand kepada konsumen agar mengetahui, mengenal, mengerti dan memahami makna dan nilai dari brand suatu perusahaan berbeda dengan pesaing. Branding yang tepat dan sukses akan membuat konsumen dengan mudah mengenali suatu brand berbeda dengan yang lain. Oleh karena itu dalam branding terdapat kegiatan positioning atau memposisikan brand dibenak konsumen.
Boomsma dan Arnoldus (2008) dalam Diarta (2015) menjelaskan bahwa berdasarkan sudut pandang penggunaan, branding memiliki beberapa pengertian atau makna. Dilihat dari sudat pandang awam, branding seringkali dipahami sebagai kegiatan promosi, iklan, atau publisitas. Dari sisi pemasar branding diartikan sebagai cara sebuah produk atau jasa dirancang agar terlihat konsumen apakah menyangkut pengemasan, logo, atau tagline. Akademisi memaknai branding sebagai proses mendesain brand termasuk nama, logo, identitas agar membentuk brand awareness dan menciptakan brand image dan attitude yang positif. Tujuan tersebut dicapai melalui bermacam-macam cara termasuk promosi dengan iklan, kemasan, dan desain produk.

Oleh karena itu branding merupakan elemen yang menjadi pertimbangan penting perusahaann dalam merencanakan strategi pemasaran suatu produk (Haimid et al., 2012) dalam Diarta, (2015). Selanjutnya Lavikka (2007) dalam (Diarta, 2015) juga menyatakan bahwa branding memberikan manfaat dalam menciptakan image atau citra produk dalam pikiran konsiuemn sehingga mereka akan mengenali dan selanjutnya membeli dan mengkonsumsi produk.

Branding bukan sekedar agar produk perusahaan dipilih dan dibeli masyarakat, tetapi juga bertujuan agar konsumen puas sehingga menjadi pelanggan setia dengan melihat perusahaan tersebut satu-satunya yang terbaik yang mampu memberikan solusi kepada mereka.

Image atau citra menurut Kotler dan Keller (2009:406) dalam Musay (2013) adalah sejumlah keyakinan, ide, dan kesan yang dipegang oleh seseorang tentang sebuah objek. Sedangkan citra merek adalah persepsi dan keyakinan yang dipegang oleh konsumen, seperti yang dicerminkan asosiasi yang tertanam dalam ingatan konsumen (Kotler dan Keller, 2009:403) dalam Musay (2013). 
Berdasarkan definisi tersebut brand image merupakan kesan yang muncul dari suatu merek dibenak konsumen. Merek dengan citra kuat dan positif selalu diingat konsumen dan mendorong konsumen untuk membeli bahkan mengikat loyalitas konsumen sehingga menjadi pelanggan setia.

Menurut Biel (1992) dalam jurnal Xian, dkk (2011:1876) dalam Musay (2013) ada tiga komponen brand image yaitu corporate image (citra perusahaan), user image (citra pemakai), dan product image (citra produk). Citra perusahaan berawal dari perasaan pelanggan dan para pelaku bisnis tentang perusahaan sekaligus sebagai hasil evaluasi individual tentang hal tersebut (Surachman, 2008:275). Citra pemakai mengacu pada kesesuaian karakteristik merek dengan konsumen. Citra produk adalah pandangan masyarakat terhadap produk atau kategori produk (Surachman 2008:275) dalam Musay (2013).

UMKM sebagai produsen pangan lokal untuk memenuhi kebutuhan dan keinginan konsumen dituntut melakukan riset untuk mengetahui keinginan konsumen terkait dengan pangan lokal. Selama ini pangan lokal kurang mendapat perhatian dan dianggap barang inferior serta kurang bergengsi.

Perkembangan dan perubahan selera konsumen yang sangat cepat maka UKMM memiliki tantangan untuk membangun image positive terhadap keunikan dan keunggulan pangan lokal yang diproduksi. Hal ini menjadi penting karena keputusan pembelian konsumen dipengaruhi oleh image positif merek. Sesuai dengan tulisan Kotler dan Amstrong (2008:181) dalam Musay (2013) yang menyatakan bahwa konsumen dalam membeli produk memilih merek yang paling disukai. Jadi merek menjadi pertimbangan konsumen dalam keputusan pembelian produk.

Mengacu pada tulisan Biel (1992) bahwa salah satu komponen brand image adalah product image (citra produk) maka pangan lokal sebagai makanan khas suatu daerah harus dilakukan branding dengan konsep mengangkat keunikan produk.

Penelitian Pradana et al., (2018) tentang Perancangan Strategi Branding "DOWRRY" di Surabaya, dilakukan dengan membangun brand makanan dengan menu basic yaitu fish and chips. "DOWRRY" membangun identitas sebagai brand makanan fish and chips melalui brand, logo hingga desain yang diaplikasikan pada media-media yang berhubungan langsung dengan konsumen sehingga dapat memengaruhi konsumen dalam menciptakan citra positif. Desain logo hingga desain yang diaplikasikan pada media-media bertujuan untuk menyampaikan identitas "DOWRRY".

DOWRRY menggunakan nama yang singkat, unik, mudah diingat, logo gambar ikan yang sederhana tetapi menunjukkan identitas produk. Pesan dan identitas DOWRRY tersampaikan dengan mudah kepada konsumen.

\section{Pentingnya Branding Pangan Lokal Untuk UMKM}

Brand dan brand image mempunyai arti penting bagi perusahaan dalam hal ini UMKM pangan lokal. Brand yang positif akan memberikan pengaruh pada perilaku pembelian konsumen. Selain itu membantu UMKM mendapatkan harga yang layak dari produk yang dihasilkan. Konsumen yang brand-minded biasanya bersedia membayar dengan harga lebih mahal terhadap brand tertentu. Oleh karena itu UMKM pangan lokal perlu membangun brand image agar konsumen mudah mengenali produk. Branding yang tepat maka akan menjadikan konsumen loyal dan memilih produk UMKM. Banyak UMKM dengan keunggulan dan keunikan mampu membangun brand image positif dan akhirnya menjadi perusahaan besar. Bahkan mampu mengikat loyalitas konsumen.

Selanjutnya brand juga menjamin produk lebih tahan terhadap goncangan harga mengingat perubahan harga tidak berpengaruh besar bagi konsumen yang loyal terhadap 
brand tertentu. Brand pada akhirnya akan mendorong peningkatan volume penjualan yang berarti peningkatan pendapatan produsen (Boomsma \& Arnoldus, 2008) dalam Diarta (2015).

Permasalahan yang dihadapi UMKM terkait branding adalah kurangnya pengetahuan tentang konsep brand dan branding, serta cara melakukan branding yang tepat dan efisien. Branding sebenarnya bisa dilakukan secara sederhana dengan memperbaiki penampilan fisik produk. Produk pangan lokal secara umum masih sederhana dengan kemasan dan label yang kurang kreatif, bahkan seringkali tanpa merek. Padahal kemasan juga berfungsi sebagai alat promosi perusahaan.

Hasil pengabdian masyarakat Wardanu et al., (2018) tentang Perbaikan Desain Kemasan Stik Ale-Ale dan Stik Kangkung Produksi KUB Wida Mantolo Di Kecamatan Benua Kayong Kabupaten Ketapang menunjukkan bahwa penggunaan desain kemasan dan labeling yang menarik mampu meningkatkan penjualan. Sebelum dilakukan pendampingan kemasan stik sangat sederhana yaitu plastik bening dengan label tulisan dari kertas. Kegiatan pendampingan bertujuan memberikan pengetahuan kepada mitra terhadap pentingnya kemasan untuk meningkatkan penjualan, branding, dan pentingnya mencantumkan informasi yang lengkap pada kemasan atau label. Kemasan produk yang baik, menarik dan marketable mampu meningkatan penjualan Stik Ale Ale dan Stik Kangkung. Konsumen yang memberikan respon baik tertarik pada kemasan stik yang baru.

Pendampingan teknik design labeling yang dilakukan Indrihastuti et al., (2019) mendapatkan sambutan dan penerimaan yang sangat bagus oleh mitra. Industri keripik salak terhambat dalam pemasaran karena belum memiliki teknik pengemasan dan desain labelling yang dipatenkan. Selain itu industri rumah tangga keripik salak juga belum memiliki brand. Setelah diberikan pendampingan, keripik salak memiliki kemasan yang menarik dengan brand/merek $\mathrm{NaCia}$. Dengan kemasan dan labelling yang menarik diharapkan industri rumah tangga keripik salak pondoh memiliki daya saing tinggi dan mampu memperluas pasar.

Kemasan yang menarik dilengkapi nama, logo, kandungan gizi, komposisi, ijin usaha dan kadaluwarsa memberikan keyakinan kepada konsumen dan memberi image yang baik kepada konsumen. Selain itu labelling juga memudahkan konsumen mengenali produk.

Produk pangan lokal yang telah memiliki brand dan legalitas maka tahap selanjutnya adalah mengkomunikasikan kepada masyarakat sehingga mereka mengenal, tertarik, mencoba membeli, dan akhirnya menjadi pelanggan setia. Seperti dijelaskan sebelumnya bahwa branding tidak hanya sekedar promosi, iklan dan publisitas. Branding pangan lokal UMKM juga sebuah proses mendesain brand. UMKM dalam melakukan branding harus mendesain nama, logo, identitas, sehingga mampu menghasilkan brand image yang positif. Branding dapat dilakukan melalui berbagai macam cara mulai dari yang sederhana termasuk periklanan, pengemasan, dan desain produk.

UMKM yang telah memiliki brand dan desain kemasan menarik maka tahap selanjutnya adalah mengkomunikasikan kepada masyarakat melalui promosi, iklan dan publisitas. Kegiatan branding agar lebih maksimal dapat dilakukan menggunakan media internet. Sosial media merupakan sarana yang sangat efektif untuk membangun image produk. Penggunaan digital marketing yang maksimal maka pangan lokal lebih cepat dikenal masyarakat secara luas. Saat ini banyak tersedia aplikasi sosial media seperti facebook, instagram, WhatsApp, telegram, 
marketplace dan banyak aplikasi lain yang dapat digunakan untuk branding produk.

Saat ini hampir semula lapisan masyarakat memiliki smartphone berbasis android. Semua informasi dengan cepat diperoleh dari smartphone tersebut. Oleh karena itu informasi terbaru produk pangan lokal segera dikomunikasikan UMKM kepada konsumen agar selalu tertarik melihat dan mengunjungi toko online UMKM. Setiap hari ada hal baru yang disampaikan kepada konsumen melalui media online tersebut.

Branding pangan lokal yang dilakukan setiap UMKM pasti berbeda-beda sesuai dengan keunikan, ciri khusus, dan keunggulan produk. Pada prinsipnya yang harus dibangun dalam melakukan branding produk pangan adalah unsur kesehatan, keamanan dan preferensi konsumen. Branding pangan lokal dapat memilih atau mengkombinasikan unsur keamanan, manfaat, layanan, rasa, atau kesehatan disesuaikan dengan image yang ingin dibangun oleh UMKM.

Sebagaimana yang dijelaskan Yuliatmoko (2011) bahwa inovasi teknologi terhadap pangan lokal bukan saja terhadap aspek mutu, gizi, dan keamanan saja tetapi juga menyentuh aspek preferensi konsumen, yaitu kesesuaian; baik kesesuaian terhadap selera, kebiasaan, kesukaan; kebudayaan, atau terlebih-lebih terhadap kepercayaan/agama.

Inovasi teknologi produk pangan lokal kaitannya dengan preferensi dapat dilakukan dengan mengkreasikan produk sesuai selera dan keinginan konsumen. Hal ini karena konsumen dalam membeli produk tidak sekedar memenuhi kebutuhan dasar tetapi juga nilai atau value dari sebuah produk. Inovasi pangan lokal agar dapat meningkatan citra positif dapat dilakukan dengan pemberian nama atau brand, bentuk produk dan kemasan, cara penyajian serta pelayanan yang sedang trend. UMKM harus selalu mengikuti perkembangan dan perubahan selera konsumen agar tidak dianggap "usang". Hal ini dapat dilakukan dengan branding produk. Untuk mewujudkan tujuan tersebut diperlukan waktu cukup lama karena UMKM harus mampu memberikan identitas yang berbeda dengan pesaing.

Pangan lokal yang diproduksi UMKM pada umumnya telah memiliki merek. Namun masih sedehana sehingga kurang menarik minat konsumen. UMKM jika telah memiliki brand tetapi dirasakan kurang memiliki nilai jual, kurang menarik minat konsumen, dan sudah ketinggalan zaaman maka bisa melakukan rebranding. Brand produk dapat diubah untuk mengikuti modernisasi. Hal ini dapat terjadi karena merek yang dibuat sebelumnya kurang mencerminkan image produk. Agar rebranding berhasil, maka melakukan penyesuaian dan strategi pemasaran yang terencana agar rebranding bisa memberikan keuntungan bagi UMKM.

\section{Branding Yang Tepat Untuk Pangan Lokal UMKM}

Kebanyakan pelaku UMKM tidak menyadari pentingnya brand terhadap produk yang dihasilkan. UMKM terlalu fokus berproduksi, dengan prinsip semua produk terjual. Walaupun produk yang dihasilkan berkualitas baik, tetapi jika tidak dilakukan branding yang tepat maka akan terjadi produk gagal di pasaran. Hal ini disebabkan produk tidak berhasil menarik perhatian dan mengkomunikasikan kualitas produk kepada konsumen.

Branding akan memberikan hasil optimal jika dengan didukung kegiatan komunikasi kepada masyarakat. Dalam mengkomunikasikan produk kepada masyarakat dilakukan dengan promosi. Penguasaan teknologi komunikasi sangat diperlukan untuk membangun brand image. Membangun komunikasi yang baik dengan masyarakat sehingga mereka percaya dan loyal pada produk.

Moka (2020) menuliskan pada dasarnya, branding terdiri dari 5 jenis, yaitu 
cultural branding, destination branding, personal branding, corporate branding, dan product branding. Cultural branding berkaitan dengan pemberian identitas merek sesuai budaya, kebiasaan suatu bangsa atau orang sesuai daerah asalnya. Destination branding menggambarkan identitas, negara, kota, daerah dan wilayah tertentu yang dimanfaatkan untuk promosi pariwisata. Personal branding adalah branding untuk perseorang. Corporate branding adalah branding yang berkaitan dengan produk yang ditawarkan, cara berkomunikasi ke pelanggan sampai kontribusi perusahaan kepada masyarakat. Product branding adalah branding dengan memberikan identitas pada produk yang diposisikan di benak konsumen dan dapat mempengaruhi konsumen untuk membeli.

Untuk pangan lokal maka strategi branding yang tepat adalah fokus pada product branding. Salah satu strategi branding yang cukup menarik agar produk dikenal masyarakat secara unik adalah brand story. Brand storytelling dapat dilakukan secara sederhana supaya tidak menimbulkan biaya tinggi. Kisah unik sebuah merek dikomunikasikan di sosial media. Pesatnya perkembangan teknologi dapat dimanfaatkan untuk melakukan branding kepada konsumen. Oleh karena itu UMKM harus merubah pola pikir dalam menjalankan bisnis dan harus mengikuti perkembangan. UMKM menggali dan mengembangan ide-ide unik dan kreatif sehingga produk lokal itu memiliki image positif dan memberi efek prestise bagi konsumen.

Brand storytelling adalah branding yang dilakukan dengan membuat kisah autentik dan emosional suatu merek untuk kegiatan promosi. Dengan brand storytelling perusahaan memperkenalkan merek melalui sebuah yang menarik sehingga konsumen lebih mengenal bagaimana sejarah dan perjalanan merek sejak awal hingga saat ini. Agar menarik brand storytelling dapat dilakukan dengan membuat cerita sederhana, mampu membuat hubungan emosional dengan konsumen, kisah yang menyentuh, narasi unik dan menjadi seorang individu. Maksud menjadi seorang individu adalah menceritakan awal mula terbentuknya merek secara nyata dengan menceritakan tentang seseorang (Desra, 2019).

Strategi ini juga diterapkan oleh produk tape Madu Sari. Hasil penelitian Yasmin et al., (2019) brand story ini menceritakan tentang proses perjalanan Ibu Linawati dari awal merintis usaha hingga beliau mencapai kesuksesan. Diciptakanlah key visual dengan visual utama Ibu Linawati, dengan pertimbangan personality produk yang menyerupai sifat dan karakter beliau. Setelah diaplikasikan ke beberapa media dan diperkenalkan kepada target audience melalui instagram, terdapat beberapa feedback yang diberikan oleh target audience, antara lain respon nostalgia target audience tentang Ibu Linawati pada saat melihat kemasan produk tape Madu Sari. Target Audience terlihat tertarik untuk mencicipi tape Madu Sari karena melihat key visual tape Madu Sari yang terlihat "jadul". Target Audience lebih meyukai postingan gambar daripada postingan tulisan pada instagram.

Konsep branding untuk membangun citra positif makanan lokal dapat menggunakan beberapa konsep. Fokus utama yang harus dilakukan UMKM adalah membuat produk unik, kemasan menarik dan selanjutnya mengkomunikasikan kepada konsumen untuk membangun image positif. Pangan lokal diubah citranya sebagai produk pangan yang modern dan diposisikan dibenak konsumen sehingga pamornya tidak kalah dengan makanan instan yang lain.

Mengkomunikasikan pangan lokal sebagai pangan modern penuh manfaat secara efektif dapat menggunakan media online. Branding dapat dilakukan menggunakan aplikasi di smartphone. Saat ini hampir semua 
Journal of Food Technology and Agroindustry Volume 3 No 1 Februari 2021

P-ISSN: 2656-0623

E-ISSN: 2684-8252

lapisan masyarakat memiliki smartphone sehingga branding dapat dilakukan lebih mudah.

Konsep branding dapat dilakukan dengan cara yang sederhana tetapi mengena di hati masyarakat. UMKM harus konsisten dalam menjaga nilai produk sehingga loyalitas konsumen terwujud. Branding tidak harus dengan biaya tinggi karena UMKM dapat memanfaatkan media online. Proses branding untuk membangun image produk memerlukan waktu cukup lama dan harus konsisten. Oleh karena itu diperlukan ketekunan dan kreativitas UMKM dalam menemukan ide kreatif untuk menarik konsumen dan menjaga loyalitas pelanggan.

\section{KESIMPULAN}

Simpulan dari kajian ini adalah branding perlu dilakukan untuk membangun

\section{DAFTAR PUSTAKA}

Amin, A. R. (2012). Penelitian Kepustakaan (Library Research). Banjir Embun. https://www.banjirembun.com/2012/04/pe nelitian-kepustakaan.html/

Dapur Ilmiah. (2014). Penelitian Literatur. Dapur Ilmiah. dapurilmiah.blogspot.com/2014/06/peneli tian-literatur.html

Desra. (2019). Brand Story. Jurnal Enterpreneur. https://doi.org/2019

Diarta, I. K. S. (2015). Branding dan 8P Sebagai Pendekatan Pemasaran Produk dan Daya Tarik Wisata Pertanian dalam Agrowisata. Promosi Agrowisata: Merajut Sinerja Dan Menjaga Keberlanjutan, 1-20.

Indrihastuti, P., Arvianti, E. Y., \& Dewi Novitawati, R. A. (2019). Teknik Design Labeling Pengembangan Model Kemasan Keripik Salak Pondoh oleh Wanita Tani Srikandi dan Karya Bhakti. JAST : Jurnal Aplikasi Sains Dan Teknologi, 3(2), 115. image positif pangan lokal agar menarik masyarakat dalam mengkonsumsi pangan lokal. Strategi branding difokuskan pada product branding. Untuk membangun image positif pangan lokal dilakukan dengan memperbaiki tampilan fisik produk, melakukan inovasi pengolahan, memperbaiki kemasan, memberikan labelling, dan memperhatikan selera konsumen. Tahap selanjutnya adalah mengkomunikasikan brand secara intensif kepada masyarakat menggunakan media online. Konsep branding dibuat sederhana, mengena di hati masyarakat, dan harus konsisten dalam menjaga nilai produk. Branding memerlukan waktu yang lama karena membangun keyakinan konsumen. Oleh karena itu UMKM harus tekun dan kreatif menemukan ide kreatif untuk menjaga loyalitas konsumen.

https://doi.org/10.33366/jast.v3i2.1471

Moka. (2020). Branding Produk: Definisi, Manfaat, dan Cara Agar Dikenal Konsumen. Blog.Mokapos.Com. https://blog.mokapos.com/cara-brandingproduk-sehingga-dikenal-konsumen

Musay, F. (2013). Pengaruh Brand Image Terhadap Keputusan Pembelian (Survei Pada Konsumen Kfc Kawi Malang). Jurnal Administrasi Bisnis S1 Universitas Brawijaya, 3(2), 74236.

Nastain, M. (2017). Branding Dan Eksistensi Produk (Kajian Teoritik Konsep Branding Dan Tantangan Eksistensi Produk). 5(1), 14-26.

Novalinda, D., \& Asni, N. (2013). Teknologi Pengolahan Pangan Lokal. BPTP Jambi.

Pradana, Y., Christine, E., Mardiono, B., Studi, P., Komunikasi, D., Seni, F., Petra, U. K., \& Siwalankerto, J. (2018). Perancangan Strategi Branding " DOWRRY " di Surabaya Pendahuluan Metode Penelitian. Jurnal DKV Adiwarna, 1 Nomor 12, 1-9. publication.petra.ac.id\%3Eindex.php\%3E 
Journal of Food Technology and Agroindustry Volume 3 No 1 Februari 2021

P-ISSN: 2656-0623

E-ISSN: 2684-8252

$\mathrm{dkv} \% 3$ Earticle\%3Eview

Vellina, V., \& Nugroho, A. (2020). Pengaruh Visual Kemasan Pada Produk Private Label Minimarket Alfamart Terhadap Keputusan Pembelian [The Influence of Packaging's Visual of Alfamart Minimart Private Label on Buying Decision]. Jurnal Titik Imaji, 3, 51-59. http://journal.ubm.ac.id/index.php/titikimaji/ Hasil

Wardanu, A. P., Martanto, \& Uliyanti. (2018). Perbaikan Desain Kemasan Stik Ale-Ale Dan Stik Kangkung Produksi KUB Wida Mantolo Di Kecamatan Benua Kayong Kabupaten Ketapang. Difusi, 1(2), 11-21.

Yasmin, A. D., Damajanti, M. N., \& Cindy Muljosumarto. (2019). Perancangan Strategi Branding Tape Madu Sari Sebagai Oleh-Oleh Khas Jember. Jurnal DKV Adiwarna, 1. http://publication.petra.ac.id/index.php/dk v/article/download/8643/7803

Yuliatmoko, W. (2011). Inovasi Teknologi Produk Pangan Lokal Untuk Percepatan Ketahanan Pangan. Universitas Terbuka, 1-8.

http://repository.ut.ac.id/2360/1/fmipa201 120.pdf 